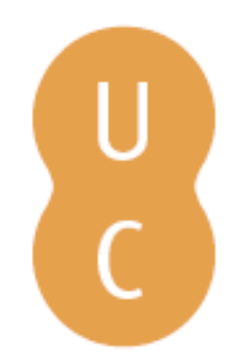

\title{
nommalina
}

\section{Fedra e a sintomatologia da paixão}

Autor(es): Lourenço, Frederico

Publicado por: Centro de Estudos Clássicos e Humanísticos da Universidade de

URL

persistente: URI:http://hdl.handle.net/10316.2/30105

DOI: $\quad$ DOI:http://dx.doi.org/10.14195/978-989-721-010-5_2

Accessed : $\quad$ 26-Apr-2023 15:50:38

A navegação consulta e descarregamento dos títulos inseridos nas Bibliotecas Digitais UC Digitalis, UC Pombalina e UC Impactum, pressupõem a aceitação plena e sem reservas dos Termos e Condições de Uso destas Bibliotecas Digitais, disponíveis em https://digitalis.uc.pt/pt-pt/termos.

Conforme exposto nos referidos Termos e Condições de Uso, o descarregamento de títulos de acesso restrito requer uma licença válida de autorização devendo o utilizador aceder ao(s) documento(s) a partir de um endereço de IP da instituição detentora da supramencionada licença.

Ao utilizador é apenas permitido o descarregamento para uso pessoal, pelo que o emprego do(s) título(s) descarregado(s) para outro fim, designadamente comercial, carece de autorização do respetivo autor ou editor da obra.

Na medida em que todas as obras da UC Digitalis se encontram protegidas pelo Código do Direito de Autor e Direitos Conexos e demais legislação aplicável, toda a cópia, parcial ou total, deste documento, nos casos em que é legalmente admitida, deverá conter ou fazer-se acompanhar por este aviso.

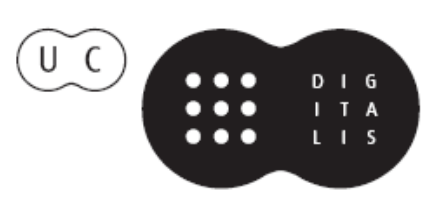




\section{Hipólito e Fedra}

\section{nos caminhos de um mito}

Carlos A. Martins de Jesus, Claudio Castro Filho, José Ribeiro Ferreira (coords.) 


\title{
Fedra e a sintomatologia da paixão
}

\author{
Frederico Lourenço \\ Universidade de Coimbra
}

Um dos aspetos que torna ainda hoje o Hipólito de Eurípides uma obra grata de ler e de encenar é sem dúvida o retrato que a peça apresenta de uma personagem dominada por uma paixão amorosa tão avassaladora quanto destrutiva. Destrutiva em sentido mortal para quem sente a paixão (Fedra), destrutiva também em sentido mortal para quem é vítima dos seus efeitos (Hipólito), e destrutiva para quem tem de sobreviver ao cenário de morte e de luto que reina no final da tragédia (neste caso a personagem em causa é Teseu).

Paixão tão autodestrutiva e tão destrutiva de outrem é, mesmo para os padrões humanos, fenómeno de exceção, e por isso Eurípides vinca a sua origem sobrenatural, exterior a quem a sente. Fedra e Hipólito são vítimas de Afrodite, deusa do amor, que castiga, por intermédio de Fedra, a recusa de Hipólito em entregar-se à vivência da sexualidade. Não é portanto Fedra que está a ser castigada por uma ofensa contra a deusa; ela é apenas o instrumento por meio do qual a vingança divina contra Hipólito é levada a cabo.

Isto faz de Fedra uma personagem duplamente interessante: Fedra não só é vítima de uma paixão inelutável, ainda para mais pelo próprio enteado; é uma vítima inocente. É certo que essa inocência se vai esvaindo ao longo da peça -e não há dúvida de que Eurípides quer no final sublinhar a superioridade ética de Hipólito relativamente a Fedra. Mas também devemos pensar que haveria muitas maneiras de retratar os sentimentos de Fedra por Hipólito. A via escolhida nesta peça é ilibadora de Fedra por ser profundamente psicológica - a paixão como acontecimento mental -; mas ao mesmo tempo não deixa de valorizar-se a manifestação somática da paixão, com descrição cuidada dos seus sintomas.

Ora o termo "sintomas" não é descabido neste contexto, pelo simples facto de se partir, logo desde o discurso inicial de Afrodite, do pressuposto explícito de que a paixão é uma doença (v. 40). Doença de que (pelo menos na cabeça de Fedra) não há cura; há apenas a possibilidade de se sair dela por meio da morte. É essa a conclusão a que Fedra chegou mesmo antes de a peça começar: já percebeu a impossibilidade da sua situação, percebeu a impossibilidade de os seus sentimentos serem correspondidos por Hipólito, percebeu o ridículo humilhante a que se prestaria se o seu estado fosse conhecido. Essencialmente, é uma relação condenada à partida pela própria situação familiar; facto de que Fedra tem consciência, mas que, no seu momento de "erro trágico", está disposta a desvalorizar, quando a Ama the oferece a miragem de o seu amor por Hipólito ser não propriamente 
correspondido, mas pelo menos sexualmente concretizado (vv. 490 e seguintes).

Esse é outro aspeto básico da situação de Fedra, a juntar à opção já referida de se entender a paixão como acontecimento mental: o desejo irreprimível que Hipólito lhe provoca. E a junção das duas realidades, a mental e a sexual, está patente com alta expressividade metafórica na frase de Fedra "a minha alma está arada pelo desejo" (vv. 504-505). A alma, portanto, como terreno trabalhado e preparado para receber a semente. Não é só o seu corpo, é também a sua alma que Fedra quer sentir fecundada por Hipólito. Isto levar-nos-ia a refletir, recordando com Maria de Fátima Silva (2005: 183) que "por trás de Fedra, é Eurípides que se compraz num exercício notável de psicologia”, sobre o que tal facto nos dirá da realidade psíquica de Fedra: poderíamos defini-la como alguém que não trabalhou o suficiente sobre si mesma, que revela défice de autoestima, que pretende anestesiar por meio da paixão e dos pensamentos obsessivos que ela provoca tudo o que está mal dentro de si própria.

No fundo, o retrato de Fedra não é de uma mulher feliz, apesar de the terem cabido na vida os atributos da felicidade (pelo menos no pensamento helénico - e não só): ter marido e filhos. Aparentemente, Fedra alcançou junto de Teseu a felicidade que fora sonegada à irmã, Ariadne, que, apaixonada por Teseu, foi abandonada por este na ilha de Naxos. Ariadne, porém, simboliza um percurso contrário ao de Fedra: é certo que Ariadne abandonada na ilha de Naxos é porventura a imagem mais expressiva que a mitologia clássica nos legou do desespero humano, desespero a que se junta outro sentimento não menos confrangedor, que antecipa a história da irmã: a depressão causada pela rejeição pelo ser amado e consequente desejo de resolver a crise existencial daí advinda pela mais radical das soluções: a morte. No entanto, contrariamente ao que sucede com Fedra, o desfecho desta crise amorosa não é a morte de Ariadne, mas antes a recompensa do sofrimento passado, sob a forma de uma felicidade sentimental que extravasa muito para lá dos parâmetros humanos, porque essa felicidade está agora ancorada na durabilidade imutável do Divino. A noiva de Teseu - transfigurada, pelo milagre do amor divino, na esposa do deus Dioniso - torna-se por isso duplamente símbolo: símbolo do desespero, sim; mas Ariadne é também testemunho não só de que o amor transforma para melhor, mas de que só a experiência do amor infeliz prepara o chão fértil donde pode nascer o amor feliz. Se, por um lado, Ariadne confirma o ditado popular de que um amor só se cura com outro amor, é também ilustração clara dos versos que surgem algo enigmaticamente numa tragédia fragmentária de Eurípides sobre este tema, tragédia a que o autor deu o título Teseu (e que trata a história de Teseu e Ariadne): 
Mas existe outro tipo de amor entre os mortais, o amor de uma alma justa, pura e generosa; deveriam os homens tomar este como regra e amar aqueles que são puros e de espírito elevado, rejeitando Afrodite, filha de Zeus (fr. 388 Kannicht) ${ }^{1}$.

Assim, poderíamos depreender que Ariadne sobe na escada do amor (para utilizarmos o termo platónico) ao curar-se do amor de Teseu, homem mortal que não teve para com ela o comportamento próprio de uma alma justa, pura e generosa; e para isso talvez nem seja necessário descontar, no novo relacionamento divino, a componente "afrodisíaca", pois, neste mito, não se tratará tanto de distinguir entre paixão erótica e amor espiritualizado, mas sim de compreender a diferença qualitativa - formulemos a questão de modo assumidamente simplista - entre o amor pela pessoa errada (Teseu) e o amor pela pessoa certa (Dioniso) ${ }^{2}$.

A situação de Fedra é radicalmente diferente. O amor, no caso dela, parece ser duplamente vivido com a "pessoa errada". Será da frustração face à vida que é a dela - o desencanto no casamento com Teseu (isto pondo de lado momentaneamente a intervenção de Afrodite) - que nasce a paixão avassaladora por Hipólito: diríamos mesmo que Fedra, no desespero da frustração e na obnubilação do desiderium mortis, chega ao ponto de precisar de fazer esta violência a si própria. Violência essa que chega ao auge, que é também o seu desfecho, no ato de se enforcar.

${ }^{1}$ A tradução destes versos segue a interpretação oferecida por T. B. L. Webster 1966: 26. A nova edição dos fragmentos de Eurípides na coleção Budé, a cargo de F. Jouan e H. van Looy, propõe uma interpretação ligeiramente diferente.

${ }^{2}$ Talvez convenha explicitar que a versão do mito de Ariadne pressuposta nas considerações que ofereci seja a que nos surge na Teogonia de Hesíodo (vv. 947-949), onde se nos depara pela primeira vez a referência à felicidade eterna de Ariadne com Dioniso, com menção explícita de que Zeus a fez imortal e livre de velhice, justamente para eternizar a felicidade do filho com a neta. Note-se que, em Homero, a versão do mito é outra. Na Odisseia (11.351-325), Ariadne é simplesmente uma das várias heroínas que Ulisses vê no Hades, no decorrer da sua visita ao mundo dos mortos. E diz-se explicitamente que ela foi morta por Ártemis na ilha de Dia (outro nome para Naxos), devido "aos testemunhos de Dioniso". A frase é enigmática e não encontramos esclarecimento cabal na própria Odisseia. Mais tarde, Ferecides, logógrafo ático do século $\mathrm{V}$ a.C., transmite-nos uma versão do mito de Ariadne que poderá ser a implícita na Odisseia. Segundo Ferecides, Teseu é coagido pela deusa Atena a abandonar Ariadne em Naxos. No entanto, depois da partida de Teseu e da chegada de Dioniso, a jovem é morta por Ártemis por ordem de Dioniso; a justificação seria a descoberta, por parte do deus, de que a amada já perdera a virgindade com Teseu. Os deuses colocam então no céu, sob a forma de constelação, a coroa dourada que Dioniso oferecera a Ariadne. Facilmente se percebe que não tenha sido esta a versão do mito a entusiasmar poetas e artistas. 
Mas já antes disso tínhamos presenciado comportamentos autodestrutivos, ainda que não tão radicais: a recusa da comida e da bebida, com a ressalva de que "recusa" implica uma escolha consciente; não sabemos se Eurípides não estaria a imaginar simplesmente a incapacidade de engolir alimentos, que é um dos sintomas da paixão levada ao extremo. Seja como for, Fedra está há três dias sem comer (vv. 135-138), o que obviamente lhe provoca o estado de fraqueza em que a vemos. E provoca-lhe também os momentos de alucinação, de loucura, que são outro sintoma da doença que é o seu estado apaixonado.

Nesses momentos de alucinação, Fedra profere palavras que, como escreve Eurípides, "tomam nos dentes o freio da loucura" (v. 214). São momentos de fusão completa com Hipólito, em que ela perde total noção de si própria, falando e sentindo como se fosse ele. É um caso óbvio da transformação do amador na coisa amada. Apesar de mulher, Fedra imagina-se a caçar e a domar cavalos (vv. 215 e seguintes), atividades a que Hipólito se dedica. A fusão possível com ele é, independentemente dele, tornar-se ele.

O que implica obviamente abdicar de si própria. Muitas vezes na peça sentimos que Fedra é uma casa na qual a própria já não consegue entrar; ou um jardim de que ela arrancou todas as árvores e plantas, para manter apenas uma única árvore, com a etiqueta "Hipólito". Jardim esse que, no entanto, já se tornara um deserto. De alguma forma, a frase que a Fedra de Marguerite Yourcenar (1974: 40) dirige a Hipólito não faz sentido no contexto da Fedra de Eurípides: “j’ai touché le fond. Je ne puis tomber plus bas que ton coeur”. Penso que a Fedra de Eurípides tem consciência de que "je ne puis tomber plus bas que mon coeur".

É sabido que Alceste, Medeia e Hipólito são três dramas euripidianos que apresentam uma característica comum: ao longo da peça, Eurípides leva o espectador a rever (de forma dir-se-ia radical) a sua perceção das duas personagens principais, a ponto de, no desfecho, ficarem invertidos os papéis do "bom" e do "mau". Isto corresponde a uma estratégia típica de Eurípides, de se recusar a propor soluções unívocas para os problemas trágicos encenados: se Medeia é vítima de Jasão, este também é vítima dela; se a nossa simpatia está com Fedra no início da peça, no final é com a nobreza de alma de Hipólito que simpatizamos; se é o egoísmo de Admeto que mais nos choca no início de Alceste, no final a sua emotividade comove-nos mais do que o altruísmo gélido da rainha.

No entanto, uma diferença marcante separa Hipólito das outras peças referidas: Hipólito e Fedra nunca trocam uma palavra. Tal como Afrodite e Ártemis, no plano divino, se situam em esferas reciprocamente impenetráveis (cf. M. C. Fialho 1996: 33-51), Fedra e Hipólito, no plano humano, vivem um desencontro predeterminado de que ambos têm plena consciência: a tragédia de Fedra é que a aceitação voluntária dessa consciência (ou compreensão 
racional) de nada vale contra a loucura involuntária de, contra o mundo e contra si mesma, estar apaixonada pelo enteado. Por sua vez, e bem ao gosto do paralelismo antagónico típico destas primeiras peças conservadas de Eurípides, é aquilo que aparentemente falta a Fedra - a castidade - que destrói Hipólito. Como ele próprio diz da madrasta morta, "foi casta sem que nela houvesse castidade; e eu, que a tenho, não obtive dela o melhor proveito" (vv. 1034-1035).

O único entrave ao plano de Afrodite é a luta interior de Fedra e a decisão de não manifestar o seu amor. A loucura é o instrumento que verga o orgulho da rainha, levando-a a fazer uma revelação que só lhe pode trazer infelicidade. Curiosa é a circunstância de, após ter verbalizado as palavras que a estavam a enlouquecer, Fedra recuperar perfeitamente a sanidade, a ponto de explicar ao Coro, de forma calma e refletida, os problemas com que se debateu ao tentar suprimir as suas emoções ("Mulheres de Trezena...", vv. 373 e seguintes). Recordemos este monólogo crucial:

Mulheres de Trezena, que habitais este derradeiro promontório do país de Pélops, já tenho reflectido, na duração arrastada da noite, sobre aquilo que destrói a vida dos mortais.

E o que me parece é que não é devido à natureza da sua compreensão que praticam o mal; pois pensar bem é apanágio de muitos. Mas devemos considerar o seguinte: reconhecemos o que está certo e compreendemo-lo, só que não o pomos em prática; uns, por inércia; outros, porque põem à frente do bem outra coisa, um prazer qualquer. Há muitos prazeres na vida... (...)

Quando percebi que estava apaixonada, pus-me a pensar na melhor maneira de aguentar o amor.

Comecei por calar e esconder a doença.

Não vale a pena confiar na língua, que sabe aconselhar os pensamentos alheios dos homens, mas que em seu próprio interesse só consegue grande quantidade de desgraças.

Em segundo lugar, decidi aguentar dignamente esta demência, vencendo-a por um esforço de reflexão sensata. Em terceiro lugar, visto que não era assim que conseguiria dominar Cípris, resolvi morrer; e ninguém negará que é a mais forte das decisões.

Este discurso de Fedra é um dos momentos altos da tragédia euripidiana, pela lucidez com que somos levados a acompanhar o trabalho de introspeção da rainha. Antes de mais, ponha-se em relevo a insónia como sintoma clássico 
da paixão (v. 375), insónia associada aos pensamentos obsessivos, circulares e labirínticos que visam "resolver" o nó; e que desabam tipicamente na conclusão de que, pelo facto de esta paixão ser indissociável da existência de Fedra, a única solução para a curar é deixar de existir. Daí que a solução para o nó dos pensamentos circulares seja o nó da corda com que Fedra se enforca ${ }^{3}$.

Só que o laço do enforcamento não resolve, de facto, a situação. Apenas remove do convívio humano a realidade somática - o corpo de Fedra - em que a paixão estava sediada. A cura da doença (seja-me permitida esta achega "psicoterapêutica") teria sido Fedra restituir-se a si própria; encontrar dentro dela algo de muito mais importante do que Hipólito: numa palavra, Fedra.

Para concluir estas breves reflexões sobre a paixão infeliz de Fedra (restaria saber se "paixão feliz" não será um oximoro...), eu diria ainda que ao suicídio de Fedra se aplicam as palavras que ouvi uma vez ao pensador católico Doutor Joaquim Cerqueira Gonçalves a propósito da eutanásia: “a vida não é um problema a resolver, é um mistério a desvendar”. Ao optar por sair da vida - ainda animicamente tapada com os véus com que, no início da peça, surge velada em cena -, Fedra não só desiste de si própria, como desiste cedo demais.

${ }^{3}$ A metáfora do nó, tanto aplicado a Fedra como a Hipólito, é conscientemente explorada por Eurípides. Há o "nó das palavras", a que Fedra se refere no v. 671; depois há o nó que faz parte do laço com que Fedra se enforca (v. 781). Finalmente, temos o "nó impossível de desatar" (v. 1237), no qual se embrincaram as rédeas do carro de cavalos, que mata Hipólito. 